\title{
QRS distortion increased risk re-occurrence acute coronary events
}

\author{
Manoefris Kasim, Sunanto, Albertus Sewianto, Dede Kusmana
}

\begin{abstract}
Abstrak
Sekitar 50\% pasien dengan infark miokard inferior akan mengalami komplikasi atau kejadian khusus yang dapat meningkatkan mortalitas. Studi ini bertujuan mengidentifikasi faktor risiko yang dominan berhubungan dengan kejadian koroner akut berulang pada pasien dengan infark miokard inferior. Kohor historis ini mencakup pasien dengan infark miokard inferior yang mendapatkan terapi fibrinolitik di unit gawat darurat Pusat Jantung Nasional Harapan Kita, Jakarta periode 2001-2004 dan diikuti dua tahun. Pasien dengan riwayat infark miokard sebelumnya, blok cabang bundel kiri, irama ventrikel, dan pacu ventrikel dikeluarkan. Distorsi QRS adalah rasio antara titik-J dan gelombang $R$ lebih dari 50\% pada 2 atau lebih sadapan inferior. Kejadian koroner akut berulang mencakup insiden infark miokard dan angina pektoris tak stabil. Dari 181 pasien dengan infark inferior, ditemukan 21 (11,6\%) insiden kejadian koroner akut berulang. Pasien dengan distorsi QRS positif dibandingkan dengan distorsi negatif memiliki risiko tiga kali lipat untuk kejadian koroner akut berulang [Risk relatif suaian $\left(R R_{a}\right) 2,88 ; 95 \%$ interval kepercayaan $\left.(I K)=1,05-7,90\right]$. Pasien dengan skor TIMI tinggi dibandingkan kelompok skor rendah memiliki risiko 6,7 kali lipat $\left(R R_{a}=6,66 ; 95 \% I K=1,94-22,92\right)$. Selain itu, pasien dengan fibrinolisis yang berhasil memiliki risiko $57 \%$ lebih rendah untuk kejadian koroner akut berulang $\left(R R_{a}=\right.$ 0,43; 95\% IK =0,18-1,05; $P=0,065)$. Kejadian koroner akut berulang berhubungan dengan distorsi QRS, skor risiko TIMI dan keberhasilan fibrinolysis. (Med J Indones 2007; 16:240-4)
\end{abstract}

\begin{abstract}
Nearly $50 \%$ of patients suffering inferior myocardial infarction will have complications or distinguishing features associated with an increased mortality. This study aimed to identify dominant risk factors related to re-occurrence of acute coronary events in patients with inferior myocardial infarction. This historical cohort included patients with inferior myocardial infarction who received fibrinolytic therapy at emergency department of National Cardiovascular Center Harapan Kita, Jakarta during 2001 to 2004 and was followed-up for two years. Patients with previous myocardial infarction, left bundle branch block, ventricular rhythm, and ventricular pacing were excluded. QRS distortion is ratio between J-point and R wave more than $50 \%$ at 2 or more inferior leads. Re-occurrence of acute coronary events is incident of myocardial infarction and unstable angina pectoris. Of 181 subjects with inferior AMI, there were $21(11.6 \%)$ incidents of acute coronary event. Those who had positive than negative QRS distortion had almost three-fold increased risk for re-occurrence of acute coronary events [adjusted relative risk $\left(R R_{a}\right) 2.88 ; 95 \%$ confidence interval $(C I)=1.05-$ 7.90]. In term of TIMI risk score, those with higher than lower risk score had 6.7 times higher risk to be re-occurrence of acute coronary events $\left(R R_{a}=6.66 ; 95 \% C I=1.94-22.92\right)$. However, those who had than did not have successful fibrinolysis had 57\% lower risk to be re-occurrence of acute coronary event $\left(R R_{a}=0.43 ; 95 \% C I=0.18-1.05 ; P=0.065\right)$. Re-occurrence acute coronary events were related to QRS distortion, TIMI risk score, and successful fibrinolysis. (Med J Indones 2007; 16:240-4)
\end{abstract}

Keywords: QRS distortion, fibrinolysis, inferior myocardial infarction

Inferior myocardial infarctions account for $40-50 \%$ of all acute myocardial infarctions, ${ }^{1,2}$ and are generally viewed as having more favorable prognosis than anterior wall infarction. However, nearly $50 \%$ of patients suffering inferior infarction will have complications or distinguishing features associated with an increased

Department of Cardiology and Vascular Medicine, Faculty of Medicine University of Indonesia, National Cardiovascular Center Harapan Kita, Jakarta, Indonesia mortality that will substantially alter an otherwise favorable prognosis. ${ }^{3}$

For an earlier assessment for prognostication of inferior myocardial infarction, size of infarction has been naturally related to the risk of mortality. One of putative marker of size of infarction is distortion of QRS complex (QRS distortion). According to its pathogenesis, QRS distortion may explain extent of ischemic event that has involved Purkinje system of ventricular conduction. Obtaining more elaborative information of initial electrocardiogram (ECG) on estimation of prognostic 
provides cost- and time-effectiveness. The aim of this study was to identify determinant risk factors related to re-occurrence of acute coronary events in patients with inferior myocardial infarction.

\section{METHODS}

This was a historical cohort including patients suffering inferior myocardial infarction who received fibrinolytic therapy at emergency department of National Cardiovascular Center Harapan Kita, Jakarta. All data was obtained from medical record archives between January 1, 2001 and December 31, 2004. Outcome was defined as re-occurrence of acute coronary events which is incident of myocardial infarction and unstable angina pectoris for 2 years follow-up.

Inclusion criteria for inferior acute myocardial infarction (AMI) are ST-segment elevation with upright $\mathrm{T}$ in lead II, III and aVF. We excluded patients with previous myocardial infarction, left bundle branch block, ventricular rhythm and ventricular pacing.

All patients were subsequently received standard treatments for the myocardial infarction in accord with the ACC/AHA Guidelines for the Management of Patients With ST-Elevation Myocardial Infarction 2004. ECG recording was done promptly after patient admitted to emergency ward. Reading of QRS distortion was done from first ECG recording on admission. Presence of distortion of QRS complex terminal in inferior AMI is defined as ratio between J-point and $\mathrm{R}$ wave more than $50 \%$ at 2 or more leads II, III or aVF (Figure 1).

To evaluate the role of determinants in predicting outcome, we did Cox-proportional hazard regression analysis. We did univariate of each variable of demographic and clinical characteristics as potential determinants of outcomes. Subsequently, multivariate analysis was done by including potenstial risk factors which had $\mathrm{P}$ value less than 0.25 . Statistic analysis was performed using STATA version 9.

\section{RESULTS}

There were 181 patients included in this study, 21 (11.6\%) incidents re-occurrence of acute coronary events. The mean of follow up time was $22.5 \pm 4.6$ months. Those who suffered re-occurrence of acute coronary events and those who did not were likely similarly distributed in term of gender, age group, family history of CAD, diabetes mellitus, and dislipidemia. However, patients with hypertension were more likely had higher risk to be re-occurrence of acute coronary events (Table 1).

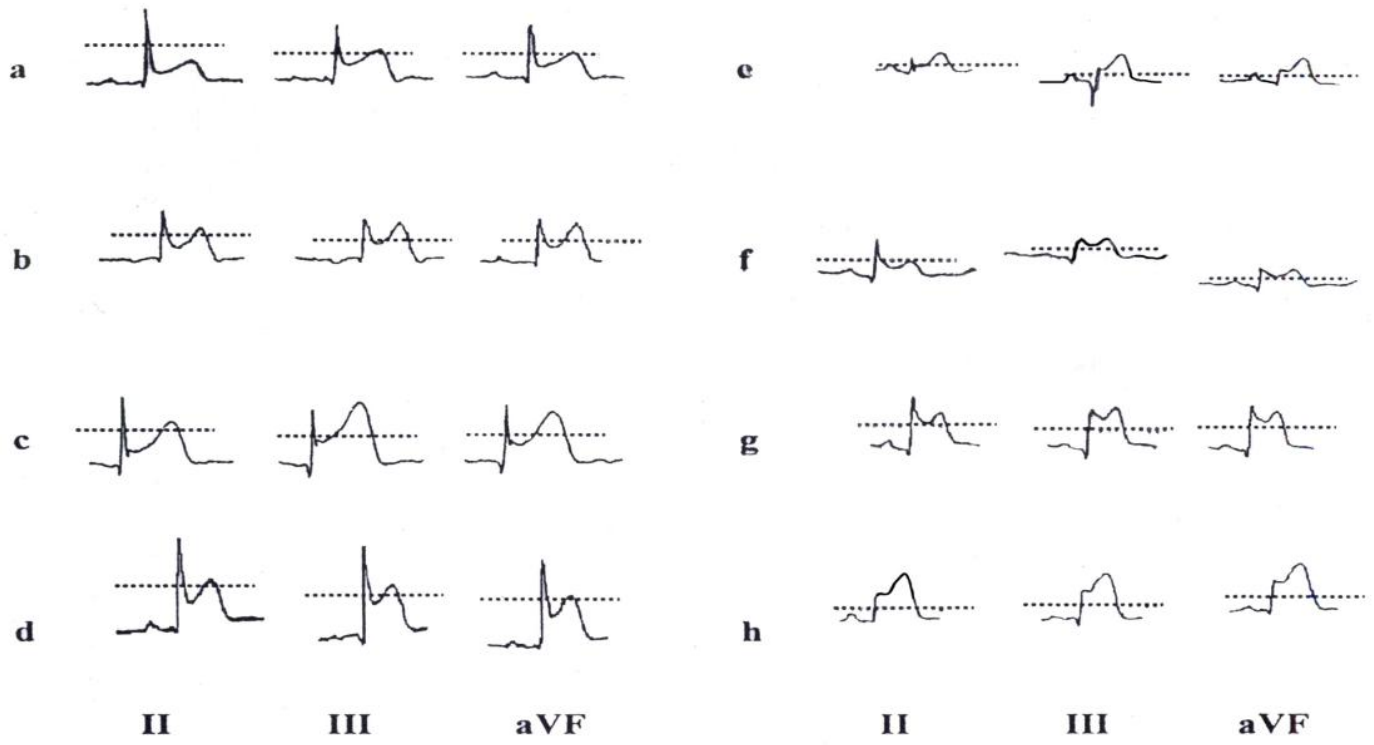

Figure 1. QRS distortion in inferior leads. Negative QRS distortion defined as ratio J-point/R wave < 50\% (a,b,c,d). Positive QRS distortion defined as ratio $J$-point/R wave $\geq 50 \%(e, f, g, h)$ 
Furthermore Table 2 shows that those who suffered re-occurrence of acute coronary events and those who did not were likely similarly distributed in term of in onset-to-admission duration, medication received during hospitalization as well. Most of patients came to emergency department in $3-5.9$ hours duration of onset-to-admission (55-61.9\%).

The final model shows (Table 3) shows that positive QRS distortion and high TIMI risk score was the strong determinant for re-occurrence of acute coronary events.

Table 1. Some demographic characteristics and risk of re-occurrence of acute coronary

\begin{tabular}{|c|c|c|c|c|c|c|c|}
\hline & \multicolumn{4}{|c|}{ Acute coronary events } & \multirow{3}{*}{$\begin{array}{l}\text { Relative } \\
\text { Risk }\end{array}$} & \multirow{3}{*}{$\begin{array}{l}\text { 95\% Confidence } \\
\text { Interval }\end{array}$} & \multirow{3}{*}{$\mathrm{P}$} \\
\hline & \multicolumn{2}{|c|}{ No $(\mathrm{N}=160)$} & \multicolumn{2}{|c|}{ Yes $(\mathrm{N}=21)$} & & & \\
\hline & $\mathrm{n}$ & $\%$ & $\mathrm{n}$ & $\%$ & & & \\
\hline \multicolumn{8}{|l|}{ Gender } \\
\hline Male & 143 & 89.4 & 17 & 81.0 & 1.00 & Reference & \\
\hline Female & 17 & 10.6 & 4 & 19.0 & 1.85 & $0.62-5.49$ & 0.269 \\
\hline \multicolumn{8}{|l|}{ Age (years) } \\
\hline $36-49$ & 31 & 19.4 & 3 & 14.3 & 1.00 & Reference & \\
\hline $50-59$ & 65 & 40.6 & 5 & 23.8 & 0.83 & $0.20-3.46$ & 0.796 \\
\hline $60-72$ & 64 & 40.0 & 13 & 61.9 & 2.00 & $0.57-7.01$ & 0.280 \\
\hline \multicolumn{8}{|c|}{ Family history of CAD } \\
\hline No & 111 & 69.4 & 15 & 71.4 & 1.00 & Reference & \\
\hline Yes & 49 & 30.6 & 6 & 28.6 & 0.93 & $0.36-2.38$ & 0.872 \\
\hline \multicolumn{8}{|l|}{ Hypertension } \\
\hline No & 125 & 78.1 & 12 & 57.1 & 1.00 & Reference & \\
\hline Yes & 35 & 21.9 & 9 & 42.9 & 2.51 & $1.06-5.97$ & 0.037 \\
\hline \multicolumn{8}{|c|}{ Diabetes mellitus } \\
\hline No & 136 & 85.0 & 16 & 76.2 & 1.00 & Reference & \\
\hline Yes & 24 & 15.0 & 5 & 23.8 & 1.71 & $0.63-4.68$ & 0.293 \\
\hline \multicolumn{8}{|l|}{ Dislipidemia } \\
\hline No & 106 & 66.3 & 12 & 57.1 & 1.00 & Reference & \\
\hline Yes & 54 & 33.8 & 9 & 42.9 & 1.46 & $0.61-3.46$ & 0.393 \\
\hline
\end{tabular}

Table 2. Onset-to-admission time of subjects in the emergency department, medications received during hospitalization and risk of re-occurrence of acute coronary events

\begin{tabular}{|c|c|c|c|c|c|c|c|}
\hline & \multicolumn{4}{|c|}{ Acute coronary events } & \multirow{3}{*}{ Relative risk } & \multirow{3}{*}{$\begin{array}{l}\text { 95\% Confidence } \\
\text { Interval }\end{array}$} & \multirow{3}{*}{$\mathrm{P}$} \\
\hline & \multicolumn{2}{|c|}{ No $(\mathrm{N}=160)$} & \multicolumn{2}{|c|}{ Yes $(\mathrm{N}=21)$} & & & \\
\hline & $\mathrm{n}$ & $\%$ & $\mathrm{n}$ & $\%$ & & & \\
\hline \multicolumn{8}{|l|}{ Onset-to-admission } \\
\hline $0.5-2.9$ hours & 60 & 37.5 & 6 & 28.6 & 1.00 & Reference & \\
\hline $3-5.9$ hours & 88 & 55.0 & 13 & 61.9 & 1.44 & $0.55-3.78$ & 0.464 \\
\hline $6-12$ hours & 12 & 7.5 & 2 & 9.5 & 1.59 & $0.32-7.89$ & 0.569 \\
\hline \multicolumn{8}{|l|}{ Nitrate } \\
\hline No & 30 & 18.8 & 6 & 28.6 & 1.00 & Reference & \\
\hline Yes & 130 & 81.3 & 15 & 71.4 & 0.59 & $0.23-1.53$ & 0.280 \\
\hline \multicolumn{8}{|l|}{ ACE inhibitor } \\
\hline No & 23 & 14.4 & 2 & 9.5 & 1.00 & Reference & \\
\hline Yes & 137 & 85.6 & 19 & 90.5 & 1.55 & $0.36-6.66$ & 0.555 \\
\hline \multicolumn{8}{|l|}{ Beta-blockers } \\
\hline No & 143 & 89.4 & 17 & 81.0 & 1.00 & Reference & \\
\hline Yes & 17 & 10.6 & 4 & 19.0 & 1.84 & $0.62-5.48$ & 0.271 \\
\hline \multicolumn{8}{|c|}{$\mathrm{Ca}^{++}$Channel Blocker } \\
\hline No & 137 & 85.6 & 19 & 90.5 & 1.00 & Reference & \\
\hline Yes & 23 & 14.4 & 2 & 9.5 & 0.63 & $0.15-2.71$ & 0.536 \\
\hline \multicolumn{8}{|l|}{ Statin } \\
\hline No & 16 & 10.0 & 2 & 9.5 & 1.00 & Reference & \\
\hline Yes & 144 & 90.0 & 19 & 90.5 & 1.05 & $0.24-4.53$ & 0.943 \\
\hline
\end{tabular}


Table 3. Relationship between TIMI risk score, QRS distortion, successful fibrinolysis and risk of re-occurrence of acute coronary events

\begin{tabular}{lcccc}
\hline & \multicolumn{2}{c}{ Acute coronary events } & Relative risk & 95\% Confidence Interval \\
\hline NIMI & & & & Pes $(\mathrm{n}=21)$ \\
$\quad$ Low risk & 97 & 3 & 1.00 & Reference \\
$\quad$ High risk & 63 & 18 & 6.66 & $1.94-22.92$ \\
$\quad$ QRS distortion & & & & \\
$\quad$ No & 86 & 5 & 1.00 & Reference \\
$\quad$ Yes & 72 & 18 & 2.88 & $1.05-7.90$ \\
Successful fibrinolysis & 45 & 13 & 1.00 & Reference \\
$\quad$ No & 115 & 8 & 0.43 & $0.18-1.05$ \\
$\quad$ Yes & & & & 0.040 \\
\hline
\end{tabular}

\section{DISCUSSION}

This study showed that QRS distortion predicted worse prognosis among patients suffering inferior myocardial infarction. Patients whose initial ECG presented positive QRS distortion have higher risk of re-occurrence of acute coronary events. Another determinant which had significant prognostic role in inferior AMI was TIMI risk score.

Shortly after occlusion of a coronary artery, serial ECG changes are detected by leads facing the ischemic zone: first, the $\mathrm{T}$ waves become tall, symmetrical, and peaked (grade I ischemia); second, there is ST elevation (grade II ischemia), without distortion of the terminal portion of the QRS; and third, changes in the terminal portion of the QRS complex appear (grade III ischemia). ${ }^{4}$ These changes include an increase in the amplitude of the $\mathrm{R}$ waves and disappearance of $\mathrm{S}$ waves. These changes in the terminal portion of the QRS are explained by prolongation of the electrical conduction in the Purkinje fibers in the ischemic region. ${ }^{5}$ The delayed conduction decreases the degree of cancellation, resulting in an increase in $R$ wave amplitude in leads with terminal $\mathrm{R}$ wave and decrease in the $\mathrm{S}$ wave amplitude in leads with terminal $\mathrm{S}$ wave on the surface ECG.

The Purkinje fibers are less sensitive to ischemia than the contracting myocytes. ${ }^{6}$ Hence, for an alteration in the terminal portion of the QRS to occur, there should probably be a severe and prolonged ischemia that would affect the Purkinje fibers. In some conditions, despite prolonged ischemia, absence of distortion may occur. It may be a sign for myocardial protection (probably by persistent myocardial flow due to subtotal occlusion or collateral circulation, or due to myocardial preconditioning).
The absolute $\mathrm{R}$ wave height is influenced by many other variables. Therefore, the absolute $\mathrm{R}$ wave amplitude is not helpful in determining the severity of ischemia. A second criterion for leads with terminal $\mathrm{R}$ configuration was developed. This criterion relates the $\mathrm{J}$ point of the ST to the $\mathrm{R}$ wave amplitude in leads with terminal $R$ waves ( $q R$ configuration).

Previous report evaluated importance of early pattern of ECG in 205 patients with first-onset myocardial infarction. ${ }^{7}$ They found that among patients with inferior myocardial infarction, mortality rate was $1.4 \%$ in group without QRS complex distortion compared to $24.1 \%$ in group with QRS distortion. The other study evaluated population study in Thrombolysis in Myocardial Infarction (TIMI) 4 which comprised of 293 grade II ischemia patients and 85 grade III patients. ${ }^{8}$ Contrary to aforementioned result, they found that patients with grade III had higher mortality risk $(6 \%)$ than patients with grade II $(3 \%)$. In subgroup of non anterior myocardial infarction, they found no difference in clinical outcome between both groups. We did not evaluated the prognostic role for mortality in this study due to inadequate validity of death in the patients since the database was achieved secondary from the medical archives which had high chance for misclassification.

Although the transition between the grades of ischemia is gradual and continuous, for practical purpose it is convenient to divide grade of ischemia as ST elevation without distortion (grade II) and with distortion (grade III). Furthermore, it is still useful to inform us the extent and longer ischemia was happened in time patient admit to emergency. Our study showed that patients with inferior myocardial infarction who came earlier to the emergency ward had not difference in outcome compared to those who came later. 


\section{Study Limitations}

First, data achieved secondary from medical record archives which may prone to incompleteness of data. We have done simple randomization for sampling and include subjects with complete data. To avoid bias selection, randomization was done blinded to outcome of subject. Second, baseline characteristic of risk factor, such as diabetes mellitus, hypertension, dislipidemia etc, may also prone to misclassification since it is recorded from secondary data. Also to avoid bias selection, the same principle of blind selection was done, so that any misclassification that may occur equally distributed to both groups. It will minimize any insult to the main result. We did not admit several variables which may be important in analysis, such as smoking, due to incompleteness and inaccuracy in the assessment of the variables. Smoking is an important but time dependent exposure for the event of acute coronary syndromes, so duration-prior-to study admission is important in assessment of smoking as determinants. In this point, we were lack of that data.

\section{CONCLUSION}

Re-occurrence acute coronary events were related to QRS distortion, TIMI risk score, and successful fibrinolysis.

\section{Aknowledgment}

The authors are grateful to Prof. Bastaman Basuki for his technical assistance.

\section{REFERENCES}

1. Gruppo Italiano per lo Studio della Streptochinasi nell'Infarto Miocardico (GISSI). Effectiveness of intravenous thrombolytic treatment in acute myocardial infarction. Lancet. 1986;1:397-402.

2. Second International Study of Infarct Survival (ISIS-2) Collaborative Group. Randomized trial of intravenous streptokinase, oral aspirin, both, or neither among 17,187 cases of suspected acute myocardial infarction: ISIS-2. J Am Coll Cardiol. 1988;12:3A-13A.

3. Berger PB, Ryan TJ. Inferior myocardial infarction. Highrisk subgroups. Circulation. 1990;81:401-11.

4. Sclarovsky S, Mager A, Kusniec J, Rechavia E, Sagie A, Bassevich R, et al. Electrocardiographic classification of acute myocardial ischemia. Isr J Med Sci. 1990;26:525-31.

5. Birnbaum Y, Mahaffey KW, Criger DA, Gates KB, Barbash GI, Barbagelata A, et al. Grade III ischemia on presentation with acute myocardial infarction predicts rapid progression of necrosis and less myocardial salvage with thrombolysis. Cardiology. 2002;97:166-74.

6. Birnbaum Y, Drew BJ. The electrocardiogram in ST elevation acute myocardial infarction: correlation with coronary anatomy and prognosis. Postgrad Med J. 2003;79:490-504.

7. Garcia-Rubira JC, Perez-Leal I, Garcia-Martinez JT, Molano F, Hidalgo R, Gomez-Barrado JJ, Cruz JM. The initial electrocardiogram pattern is a strong predictor of outcome in acute myocardial infarction. Int $\mathbf{J}$ Cardiol. 1995;51:301-5.

8. Birnbaum Y, Kloner RA, Sclarovsky S, Cannon CP, McCabe $\mathrm{CH}$, Davis VG, et al. Distortion of the terminal portion of the QRS on the admission electrocardiogram in acute myocardial infarction and correlation with infarct size and long-term prognosis (Thrombolysis in Myocardial Infarction 4 Trial). Am J Cardiol. 1996;78:396-403. 